\title{
Acute Exacerbations and Respiratory Failure in Chronic Obstructive Pulmonary Disease
}

\author{
Neil Maclntyre ${ }^{1}$ and Yuh Chin Huang ${ }^{1}$ \\ ${ }^{1}$ Duke University Medical Center, Durham, North Carolina
}

\begin{abstract}
Acute exacerbations of chronic obstructive pulmonary disease (AECOPD) describe the phenomenon of sudden worsening in airway function and respiratory symptoms in patients with COPD. These exacerbations can range from self-limited diseases to episodes of florid respiratory failure requiring mechanical ventilation. The average patient with COPD experiences two such episodes annually, and they account for significant consumption of health care resources. Although bacterial infections are the most common causes of AECOPD, viral infections and environmental stresses are also implicated. AECOPD episodes can be triggered or complicated by other comorbidities, such as heart disease, other lung diseases (e.g., pulmonary emboli, aspiration, pneumothorax), or systemic processes. Pharmacologic management includes bronchodilators, corticosteroids, and antibiotics in most patients. Oxygen, physical therapy, mucolytics, and airway clearance devices may be useful in selected patients. In hypercapneic respiratory failure, noninvasive positive pressure ventilation may allow time for other therapies to work and thus avoid endotracheal intubation. If the patient requires invasive mechanical ventilation, the focus should be on avoiding ventilatorinduced lung injury and minimizing intrinsic positive end-expiratory pressure. These may require limiting ventilation and "permissive hypercapnia." Although mild episodes of AECOPD are generally reversible, more severe forms of respiratory failure are associated with a substantial mortality and a prolonged period of disability in survivors.
\end{abstract}

Keywords: chronic obstructive pulmonary disease; pulmonary infections; respiratory failure; mechanical ventilation

\section{DEFINITION AND IMPACT}

An acute exacerbation of chronic obstructive pulmonary disease (AECOPD) is a clinical diagnosis made when a patient with COPD experiences a sustained (e.g., 24-48 h) increase in cough, sputum production, and/or dyspnea. AECOPD has clinical consequences ranging from a self-limited illness to progressive respiratory failure (1-4). AECOPD was responsible for 1.5 million emergency department visits, 726,000 hospitalizations, and approximately 119,000 deaths in $2000(5,6)$. The annual hospitalization rate for COPD in the United States increased from 9.7 to 24.5 per 10,000 population between 1988 and 1998, and the vast majority of these were due to $\operatorname{AECOPD}(5,6)$. The average patient with COPD experiences two episodes of AECOPD per year,

(Received in original form July 5, 2007; accepted in final form August 8, 2007) The National Emphysema Treatment Trial (NETT) is supported by contracts with the National Heart, Lung, and Blood Institute (N01HR76101, N01HR76102, N01HR76103, N01HR76104, N01HR76105, N01HR76106, N01HR76107, N01HR76108, N01HR76109, N01HR76110, N01HR76111, N01HR76112, N01HR76113, N01HR76114, N01HR76115, N01HR76116, N01HR76118, and N01HR76119), the Centers for Medicare and Medicaid Services (CMS), and the Agency for Healthcare Research and Quality (AHRQ).

Correspondence and requests for reprints should be addressed to Neil Maclntyre, M.D., Box 3911, Duke University Medical Center, Durham, NC 27710. E-mail: neil.macintyre@duke.edu

Proc Am Thorac Soc Vol 5. pp 530-535, 2008

DOI: 10.1513/pats.200707-088ET

Internet address: www.atsjournals.org and $10 \%$ of these episodes require hospitalization (5). The average duration of an episode is 7 days, although it may take several months for the patient to return to baseline functional status $(2,3,6)$. More recent data from the National Emphysema Treatment Trial show that patients with severe emphysema and who are eligible for lung volume reduction surgery have 6.1 days/ year of hospitalization if they remain on medical therapy but only 3.2 days/year if given lung volume reduction surgery $(P=0.005)$ (7).

\section{ETIOLOGY AND CONFOUNDING FACTORS}

Bacterial infections are implicated in the majority of AECOPD episodes (2,8-12). This is not surprising because the patient with COPD has airways that are prone to infections, with impaired local defenses and frequent bacterial colonization. Sputum and bronchoscopy data have shown that Moraxella catarrhalis, Haemophilus influenza, and Streptococcus pneumonia are the most common organisms associated with AECOPD episodes (8-11). Other bacteria (e.g., Pseudomonas and Staphylococcus) have also been implicated. Many of these bacteria may be chronic airway colonizers that progress to infection after a simple viral upper respiratory infection or an environmental stress. On the other hand, a significant number of AECOPD infections may come from bacterial strains that are new to the patient (8-11).

Infectious AECOPD can be caused by other agents. Rhinovirus and respiratory syncytial virus have been implicated as causes for AECOPD in several studies (13-17). During the influenza season, the prevalent strain of influenza virus may also be an important viral cause, especially in the elderly. Other viruses, such as parainfluenza virus, adenovirus, and picornavirus, may be important, but their role in AECOPD is less clear. Atypical microorganisms such as Mycoplasma pneumoniae and Chlamydia have been implicated in $5-15 \%$ and $5-10 \%$ of AECOPD cases, respectively $(12,16,17)$. Patients with infectious exacerbations have longer hospitalizations and greater impairment of several measures of lung function than those with noninfectious exacerbations (8).

Air pollution is another important factor in AECOPD (1823). Epidemiological research has linked increases in respiratory symptoms, admissions for exacerbations, and COPD-associated mortality with air pollutants such as particulate matter, sulfur dioxide, ozone, and nitrogen oxides. It has been estimated that up to $9 \%$ of admissions with AECOPD may be due to atmospheric pollution, especially during the summer months (23).

Cardiac dysfunction may be another important factor in AECOPD (24). Acute left heart dysfunction was present in 25$30 \%$ of patients with AECOPD (25-27). Congestive heart failure is an independent risk factor for survival in patients with COPD who had acute exacerbations requiring hospitalization (28). Decompensation of cardiac function may present as right heart failure (cor pulmonale) precipitated by hypoxia-induced pulmonary hypertension, pulmonary embolism, or pneumonia $(29,30)$. Left heart failure is common because many patients with COPD have coronary artery disease and hypertensive heart disease as comorbid conditions (24). Decreased cardiac output reduces oxygen delivery to respiratory muscles, contributing to respiratory 
decompensation in patients with COPD $(1,24)$. Pulmonary embolism is an uncommon trigger for acute exacerbation (31), although in patients with acute exacerbation of unknown origin, the prevalence may be as high as $25 \%$ (32). Other conditions, such as nonpulmonary infections and pneumothorax, can mimic an acute exacerbation or possibly act as triggers (1-3).

In about $30 \%$ of cases of AECOPD, no specific etiology could be identified. Many of these episodes may represent the fluctuating natural progression of COPD or noncompliance to maintenance treatment. It is possible that some of these episodes were triggered by infection, but the microorganisms are not identified due to the lack of sensitive technology.

Recent development in plasma biomarkers may help assess AECOPD and provide prognosis. For example, elevation of troponins was associated with increased severity of the exacerbation (25). Troponin $\mathrm{T}$ and amino-terminal pro-brain natriuretic peptide are elevated in patients with acute left heart failure and may be used to exclude left ventricular dysfunction as the cause of AECOPD $(26,27)$. Elevation of C-reactive protein, an acutephase reactant, may help confirm the diagnosis of AECOPD, but it is nonspecific and cannot differentiate between infectious and noninfectious causes of AECOPD (33-35). D-dimer may also assist in diagnosing pulmonary embolism associated with AECOPD $(31,36)$.

\section{CLINICAL PICTURE}

The clinical manifestations of exacerbations of COPD are highly variable. Patients with AECOPD may present with symptoms and signs similar to those at baseline except with greater severity. Orthopnea and paroxysmal nocturnal dyspnea that are usually not present at baseline may become evident when congestive heart failure coexists. On physical examination, there may be increased expiratory wheezes and rhonchi. Breath sounds or wheezing may decrease if the airway obstruction is severe. There is usually more prominent use of accessory muscle. Signs of muscle fatigue, such as paradoxical breathing (an inward motion of the upper abdominal wall with inspiration) and respiratory alternans (a cyclic alternation between abdominal and rib cage breathing), may be present and should raise suspicion of impending respiratory failure.

With AECOPD, cough may become more severe and strenuous. Sputum volume may increase, and the color of the sputum may change from whitish to yellow or green. Hemoptysis is not uncommon during AECOPD and may consist of streaks or specks of blood mixed in purulent sputum. Occasionally, hemoptysis may be of larger quantity. In this case, other causes, including lung cancer, pneumonia, bronchiectasis, and heart failure, should be considered.

There may be signs of worsening right ventricular failure during AECOPD, including jugular venous distension, hepatic congestion, and lower extremity edema, especially in patients with advanced COPD and chronic hypoxemia. Many factors that trigger acute exacerbations typically increase ventilationperfusion $(\dot{\mathrm{V}} / \dot{\mathrm{Q}})$ mismatch and hypoxemia $(37,38)$. This worsens pulmonary hypertension and produces right ventricular overload and, eventually, cor pulmonale $(30,39)$. The develop- ment of cor pulmonale is a particularly ominous sign in COPD and is a major cause of mortality $(40,41)$. In severe cases of acute exacerbation, muscle overload may occur, and hypercapnic respiratory failure may develop.

Central nervous system symptoms may be present, ranging from irritability to decreased responsiveness secondary to worsening hypoxemia, hypercapnea, or both. Central nervous system symptoms may precede respiratory symptoms or be the only recognizable clinical manifestation, especially in elderly patients with baseline hypercapnea.

\section{STAGING AECOPD}

The severity of AECOPD without respiratory failure can be classified according to several staging systems. The traditional system uses the Winnipeg criteria, which were derived from a double-blind, placebo-controlled trial that evaluated the role of antibiotics in patients with COPD with acute exacerbations (42). The three-stage system is based on three principal symptoms: increase in sputum volume, increase in sputum purulence, and increase in shortness of breath (Table 1). This staging system correlates well with the effectiveness of antibiotic treatment for AECOPD. In type 1 exacerbations, antibiotics reduce the risk of treatment failure, whereas the effects of antibiotics are virtually absent in type 3. The Canadian Medical Association recently published guidelines for the management of AECOPD based on a five-stage severity system (43). The system grades the severity based on the classic Winnipeg criteria and some of the factors known to correlate with poorer response to therapy, including age greater than 65 years, significant comorbid illness, $\mathrm{FEV}_{1}$ less than $50 \%$ of predicted, and number of exacerbations per year. The antibiotic therapy is adjusted according to the severity of the exacerbation. Another three-level staging system for AECOPD has been proposed that incorporates symptoms criteria and history of the disease and comorbidity (44).

Although these more comprehensive severity-scoring systems may allow a more rational choice of antibiotics for AECOPD, they provide little guidance for nonantimicrobial therapies. In addition, none of these systems has been validated prospectively. Because of the array of different therapies aimed at different physiological derangements in acute exacerbations of COPD, no single severity scale will likely be sufficient to guide treatment decisions in an acute exacerbation of COPD. It may be necessary to have one scale related to likely microbial pathogens to guide antibiotic treatment, another to assess airway reactivity and likely response to different bronchodilator treatments, and another to assess ventilatory function and the need for mechanical ventilatory support and intensive care unit (ICU) care. Theoretically, these measures could be combined into one severity score system for the initial assessment of patients with AECOPD. Any such scoring systems would have to be tested formally before they could be used in clinical decision making.

It is important in the initial assessment of AECOPD to determine the need for hospitalization. Patients with more severe baseline disease are more likely to require hospital admission dur-

\section{TABLE 1. THE WINNIPEG CRITERIA}

Type of Exacerbations

Type 1

Type 2

Type 3
All three of the following symptoms: increase in sputum volume, increase in sputum purulence, increase in shortness of breath Any two of the following symptoms: increase in sputum volume, increase in sputum purulence, increase in shortness of breath Any one of the following symptoms: increase in sputum volume, increase in sputum purulence, increase in shortness of breath, plus at least one of the following: upper respiratory tract infection lasting $5 \mathrm{~d}$, fever; increase in wheezes, increase in cough, increase in heart rate $\geqslant 20 \%$ 
TABLE 2. INDICATORS OF NEED FOR HOSPITALIZATION IN ACUTE EXACERBATION OF CHRONIC OBSTRUCTIVE PULMONARY DISEASE

Older age

Severe underlying chronic obstructive pulmonary disease/already receiving long-term oxygen therapy

Marked increase in breathlessness

Poor or deteriorating general condition with little activity

Cyanosis or worsening peripheral edema

Impaired level of consciousness or confusion

Difficulty in coping at home

Significant comorbidities (particularly arrhythmias, heart failure, and insulin-dependent diabetes)

Failure to respond to initial medical treatment

Oxygen saturation $<90 \%$

ing acute exacerbations. Some indicators of the need for hospitalization are shown in Table 2 (45). Patients with AECOPD who have at least a few of these indicators should be admitted to the hospital for further management. When signs of respiratory failure or impaired consciousness occur, management in the ICU is needed.

\section{PHARMACOLOGIC MANAGEMENT OF AECOPD}

\section{Bronchodilators}

The use of short-acting $\beta$-agonists, theophylline, and anticholinergic bronchodilators is based on the concept that the smooth muscle reactivity, airway inflammation, and mucus production characteristics of AECOPD episodes should respond to these drugs. Numerous clinical trials have supported the use of these drugs $(2,46)$. In comparing $\beta$-agonists, albuterol given every 20 minutes seemed to provide an equal effect on $\mathrm{FEV}_{1}$ as albuterol given every hour, and nebulized albuterol seemed comparable to subcutaneous terbutaline (46). Extrapolating from the asthma literature, a number of observational trials have shown efficacy for continuous albuterol nebulization (47). In a large meta-analysis of administration techniques, no difference was found in bronchodilator effect if the drugs were given in a metered dose inhaler or in a small-volume nebulizer (48).

\section{Antiinflammatory (Corticosteroid) Therapy}

The chronic airway inflammation in COPD becomes an acute airway inflammation during an AECOPD episode. As in an acute asthma flare, there is a rationale for corticosteroid (CS) therapy. Supporting this concept are a number of randomized clinical trials in AECOPD that showed that CS therapy improved pulmonary function testing more rapidly and shortened the length of the exacerbation period compared with placebo (49) (Table 3). Not all these studies were positive. In the largest of the positive studies, a regimen of $125 \mathrm{mg}$ methylprednisolone every 6 hours for 72 hours followed by $60 \mathrm{mg}$ prednisone daily tapered for 2 weeks was found to be most cost-effective.

The data supporting CS therapy in AECOPD episodes used oral or parenteral CS preparations. Whether inhaled corticosteroids (ICS) could provide a similar benefit is less clear. The effectiveness of ICS therapy depends heavily upon the patient's ability to properly perform the aerosol delivery maneuvers, something that may be difficult in the dyspneic patient with an AECOPD episode.

\section{Antibiotics}

Because of the importance of bacterial infection in most AECOPD episodes, the Global Obstructive Lung Disease and American Thoracic Society COPD guidelines recommend antibiotic use during these episodes (www.goldcopd.com, www. thoracic.org). Many studies have shown that routine antibiotics shortened the severity and/or the duration of an AECOPD episode, but this finding is not universal. A meta-analysis in 1995 demonstrated a statistically significant effect in favor of giving routine antibiotics (50). The choice of antibiotics depends on the likely organism. Treating an AECOPD episode early improves the speed of functional recovery.

\section{Other Therapies}

During an AECOPD episode, other modalities that are useful include mucolytics/chest physical therapy in selected patients who have copious retained secretions $(51,52)$. Supplemental oxygen may be helpful, but because oxygen therapy can be associated with worsening hypercapnia from combinations of ventilatory drive blunting, the Haldane effect in the red blood cell, and derangements in $\dot{\mathrm{V}} / \dot{\mathrm{Q}}$ relationships, oxygen therapy should be targeted to provide the minimal amount to maintain acceptable oxygenation (e.g., $\mathrm{Sp}_{\mathrm{O}_{2}}$ values of $>89 \%$ ) $(37,38)$. Airway clearance devices for patients with significant airway secretions range from simple airway vibratory/expiratory pressure devices to sophisticated airway or external percussors. Although these devices have been shown to increase sputum clearance, their effects on outcome have not been evaluated in clinical trials (52).

\section{MECHANICAL VENTILATION ISSUES FOR HYPERCAPNIC RESPIRATORY FAILURE}

Respiratory failure from airflow obstruction is a direct consequence of acute airway narrowing and critical increases in airway resistance. These lead to two important mechanical changes. First, the increased pressures required for airflow may overload respiratory muscles, producing a "ventilatory pump failure" with spontaneous minute ventilation inadequate for gas exchange (hypercapneic respiratory failure). Second, the narrowed airways create regions of lung that cannot properly empty and return to their normal resting volume. This sometimes is called air trapping and produces elevated end-expiratory pressures (intrinsic positive end-expiratory pressure [PEEPi] or auto-PEEP). These regions of overinflation put inspiratory muscles at a substantial mechanical disadvantage, which further worsens respiratory muscle function (53). Overinflated regions may compress more healthy regions of the lung, impairing $\dot{\mathrm{V}} / \dot{\mathrm{Q}}$ matching. The high intrathoracic pressures may impair cardiac filling and contribute to overdistention lung injury (54). During spontaneous efforts, regions of air trapping and PEEPi can function as a threshold load to trigger assisted breaths, which can further overload ventilatory muscles $(53,55)$.

If short-term muscle rest could be achieved with noninvasive positive pressure ventilation (NPPV) through a nasal or oral mask, the pharmacologic agents given for AECOPD might be given time to work and thus avert a need for invasive mechanical ventilation. Evaluating this concept are a number of randomized and/or crossover studies using NPPV in the initial phases of severe AECOPD (56). Although there are mixed results, the two largest studies of NPPV in AECOPD (56) showed that NPPV reduced the need for invasive mechanical ventilatory support. The decision to discontinue NPPV and proceed to invasive mechanical ventilatory support is a clinical one usually driven by progressive respiratory acidosis and signs of patient fatigue/ discomfort during NPPV.

In general, the overall goals of invasive mechanical ventilatory support in respiratory failure due to airflow obstruction are similar to the overall goals in other forms of respiratory failure, providing adequate gas exchange while minimizing lung injury. 
TABLE 3. CORTICOSTEROID THERAPY DURING ACUTE EXACERBATION OF CHRONIC OBSTRUCTIVE PULMONARY DISEASE

\begin{tabular}{|c|c|c|c|}
\hline Study (yr) & Number of Patients & Design & Results \\
\hline Albert $(1980)^{\star}$ & 44 & RCT & Steroids improved $\mathrm{FEV}_{1}$ \\
\hline Emmerman (1989) ${ }^{\dagger}$ & 100 & RCT & Steroids had no effect \\
\hline Bullard $(1996)^{\ddagger}$ & 138 & $\mathrm{RCT}$ & Steroids improved $\mathrm{FEV}_{1}$, not hospitalization rates \\
\hline Thompson $(1996)^{\S}$ & 27 & $\mathrm{RCT}$ & Steroids improved $\mathrm{FEV}_{1}$ \\
\hline Davies (1999)\| & 56 & $\mathrm{RCT}$ & Steroids improved $\mathrm{FEV}_{1}$, not subsequent walk test or $\mathrm{FEV}_{1}$ \\
\hline Niewoehner (1999) & 271 & RCT & Steroids reduced treatment failures, not long-term outcome \\
\hline
\end{tabular}

Definition of abbreviation: RCT = randomized controlled trial.

Data from Reference 40.

* Albert RK, Martin TR, Lewis SW. Controlled clinical trial of methylprednisolone in patients with chronic bronchitis and acute respiratory insufficiency. Ann Intern Med 1980;92:753-758.

${ }^{\dagger}$ Emerman CL, Connors AF, Lukens TW, May ME, Effron D. A randomized controlled trial of methylprednisolone in the emergency treatment of acute exacerbations of COPD. Chest 1989;95:563-567.

$¥$ Bullard W, Burgi H, Landis E. Early corticosteroid use in acute exacerbations of chronic airflow obstruction. Am J Emerg Med 1996;14:139-143.

$\S$ Thompson WH, Nielson CP, Carvalho P, Charan NB, Crowley JJ. Controlled trial of oral prednisone in outpatients with acute COPD exacerbation. Am / Respir Crit Care Med 1996;154:407-412.

" Davies L, Angus RM, Calverley PMA. Oral corticosteroids in patients admitted to hospital with exacerbations of chronic obstructive pulmonary disease: a prospective randomised controlled trial. Lancet 1999;354:456-460.

` Niewoehner DE, Erbland ML, Deupree RH, Collins D, Gross NJ, Light RW, Anderson P, Morgan NA. Effect of systemic glucocorticoids on exacerbations of chronic obstructive pulmonary disease. N Engl J Med 1999;340:1941-1947.

Two particularly important considerations in respiratory failure from AECOPD are minimizing regional overdistention and managing PEEPi. Overdistention injury occurs when excessive end-inspiratory alveolar "stretch" physically damages alveolar structures and produces local and systemic inflammation (ventilator-induced lung injury [VILI]) (54). Clinically this occurs when the end-inspiratory stretching pressure (often estimated by the end-inspiratory airway plateau pressure) exceeds the normal physiological maximum of $30 \mathrm{~cm} \mathrm{H}_{2} \mathrm{O}$ (54). This stretch injury may be a consequence of excessive tidal volumes, even when the plateau pressure is less than $30 \mathrm{~cm} \mathrm{H}_{2} \mathrm{O}(57,58)$. These effects have been most studied in patients with parenchymal lung injury, but protecting alveolar structures would seem to be a mechanical ventilation goal in virtually all forms of respiratory failure (59). This has led to recommendations to reduce tidal volumes (e.g., 5-7 ml/kg) to protect the lung in AECOPD. To avoid intrinsic PEEP buildup from resulting in patient tachypnea, moderate sedation may be required. The resulting reduction in minute ventilation may produce progressive hypercapnia (so-called permissive hypercapnia). However, accepting $\mathrm{pH}$ values in the 7.0-7.1 range may have little clinical effect on the patient and may be beneficial if the reduced volumes and pressures reduce the risk of VILI $(60,61)$. There is emerging evidence (although not universal) that a modest respiratory acidosis may ameliorate cellular injury $(62,63)$.

Narrowed airways produce a high resistance to flow that can result in very high peak airway pressures. Much of this pressure is dissipated in providing gas flow through obstructed airways and therefore does not overdistend distal alveoli. However, the heterogeneous distribution of airflow obstruction seen in most airway diseases means that less obstructed alveolar regions may transiently be exposed to these high peak pressures and thus may be at risk for overdistention injury. Because of this, a high peak pressure, even in the presence of acceptable plateau pressures, should be avoided.

The second important consideration in managing the patient with AECOPD who has respiratory failure involves PEEPi. PEEPi is a function of three variables: minute ventilation, inspiratory/ expiratory ( $\mathrm{I} / \mathrm{E})$ time ratios, and expiratory time constants (resistance $\times$ compliance) (64). An increase in any of these values increases the risk of PEEPi. Reducing PEEPi thus requires reductions in any or all of these-reducing minute ventilation (permissive hypercapnia), a shorter I/E that lengthens the expiratory time, or reductions in airway resistance using pharmacologic agents. If the PEEPi is causing a significant ventilator breath-triggering load on the patient, judicious amounts of applied circuit PEEP can equilibrate expiratory pressures and thereby reduce this triggering work $(55,65,66)$. An esophageal balloon often can be helpful in detecting and managing this phenomenon. In severe airway obstruction, uses of low-density gases (e.g., $80: 20,70: 30$, or 60:40 helium/oxygen or heliox) can help reduce patient inspiratory work and facilitate lung emptying (driving pressure decreases and/or flow increases through a tube as gas density decreases) (67). If a helium/oxygen gas mixture is used, many flow sensors must be recalibrated to account for the change in gas density. Some ventilators cannot function in the presence of heliox.

Withdrawing mechanical ventilatory support after improvement in AECOPD respiratory failure should follow evidencebased guidelines for other forms of respiratory failure (68). In general, daily spontaneous breathing trials should be performed as patients recover, and patients should be managed with comfortable forms of assisted ventilation (e.g., pressure support, pressure assist, or proportional assist) in between the spontaneous breathing trials. There is some evidence that earlier extubations in patients with AECOPD might be facilitated with conversion to NPPV $(69,70)$. However, these trials are too small and insufficient to support broad recommendations for practice changes. In managing patients with airflow obstruction on a ventilator, techniques to deliver bronchodilator aerosols through the ventilator circuitry must be used. This generally involves in-line circuit nebulizers, although metered dose inhalers with inspiratory circuitholding chambers are also effective $(71,72)$. Because endotracheal tubes significantly reduce aerosol delivery, doses usually are increased three- to fourfold (or aerosolized continuously) to ensure adequate drug effectiveness. Assessment of airway pressures (peak to plateau gradients) or flow-volume patterns can be used to monitor bronchodilator effectiveness.

\section{OUTCOMES OF AECOPD}

Most exacerbations in patients with COPD are relatively mild, requiring only outpatient care, but $3-16 \%$ of these require hospital admission, and some cases are severe enough to result 
in respiratory failure requiring ICU intervention. AECOPD episodes have been shown to accelerate $\mathrm{FEV}_{1}$ decline, to increase mortality (AECOPD episodes are the most common cause of death in COPD), and to have a profound influence on the decline in quality of life scores $(4,6,73,76)$.

One large survey found an in-hospital mortality rate of $11 \%$ and 1-year mortality rate of $43 \%$ in patients with COPD admitted for acute exacerbations (28). Another recent study found a similar in-hospital mortality rate (8\%) and 1-year mortality rate $(23 \%)$ (73). These mortality figures are much higher for patients requiring ICU admission (74-76).

Mortality is substantial in patients with COPD who require mechanical ventilation (although it is better than in patients with acute lung injury/acute respiratory distress syndrome) (74). In one large study, in hospital mortality in mechanically ventilated patients with AECOPD was almost 25\%, 1-year mortality approached $40 \%$, and 5 -year mortality exceeded $70 \%$ (75). Survivors of respiratory failure from COPD tend to return to baseline lung function very slowly (i.e., weeks to months). In a large, multicenter study, the need for mechanical ventilation did not influence outcome in patients with COPD admitted to an ICU (41). However, the risk for rehospitalization and reintubation for patients with COPD is increased markedly after an episode of respiratory failure requiring mechanical ventilation (41).

\section{CONCLUSIONS}

AECOPD afflict millions of patients with COPD annually and account for substantial health care costs. Although bacterial infections are the most common causes of AECOPD, viral infections and environmental stresses are also implicated. AECOPD episodes can be triggered or complicated by other comorbidities. Pharmacologic management includes bronchodilators, corticosteroids, and antibiotics in most patients. Oxygen, physical therapy, mucolytics, and airway clearance devices may be useful in selected patients. In hypercapneic respiratory failure, NPPV may allow other therapies to work and thus avoid endotracheal intubation. If the patient requires invasive mechanical ventilatory support, the focus should be on avoiding VILI and minimizing intrinsic PEEP. These may require limiting ventilation and socalled permissive hypercapnia. Although mild episodes of AECOPD are generally reversible, more severe forms of respiratory failure are associated with a substantial mortality and a prolonged period of disability in survivors.

Conflict of Interest Statement: N.M. received lecture fees from Pfizer, Boehringer Ingelheim and Dey Labs. Y.C.H. has participated as a speaker in workshops organized and financed by Hamilton Medical, Inc. He received \$2,500 in 2006 and $\$ 1,000$ in 2007.

\section{References}

1. O'Donnell DE, Parker CM. COPD exacerbations: pathophysiology. Thorax 2006;61:354-361.

2. Bach PB, Brown C, Gelfand SE, McCrory DC. Management of acute exacerbations of chronic obstructive pulmonary disease: a summary and appraisal of published evidence. Ann Intern Med 2001;134:600620.

3. Ball P. Epidemiology and treatment of chronic bronchitis and its exacerbations. Chest 1995;108:43S-52S.

4. Celli BR, Barnes PJ. Exacerbations of chronic obstructive pulmonary disease. Eur Respir J 2007;29:1224-1238.

5. Sullivan SD, Ramsey SD, Lee TA. The economic burden of COPD. Chest 2000;117:5S-9S.

6. Mannino DM, Homa DM, Akinbami LJ, Ford ES, Redd SC. Chronic obstructive pulmonary disease surveillance-United States, 1971-2000. Respir Care 2002;47:1184-1199.

7. Ramsey SD. Berry K. Etzioni R, Kaplan RM, Sullivan SD, Wood DE; National Emphysema Treatment Trial Group. Cost effectiveness of lung-volume-reduction surgery for patients with severe emphysema. N Engl J Med 2003;348:2092-2102.

8. Papi A, Bellettato CM, Braccioni F, Romagnoli M, Casolari P, Caramori G, Fabbri LM, Johnston SL. Infections and airway inflammation in chronic obstructive pulmonary disease severe exacerbations. Am J Respir Crit Care Med 2006;173:1114-1121.

9. Fagon JY, Chastre J, Trouillet JL, Domart Y, Dombret MC, Bornet M, Gilbert C. Characterization of distal bronchial microflora during acute exacerbation of chronic bronchitis use of the protected specimen brush technique in 54 mechanically ventilated patients. Am Rev Respir Dis 1990;142:1004-1008.

10. Monsó E, Ruiz J, Rosell A, Manterola J, Fiz J, Morera J, Ausina V. Bacterial infection in chronic obstructive pulmonary disease: a study of stable and exacerbated outpatients using the protected specimen brush. Am J Respir Crit Care Med 1995;152:1316-1320.

11. Sethi S, Evans N, Grant BJ, Murphy TF. New strains of bacteria and exacerbations of chronic obstructive pulmonary disease. $N$ Engl $J$ Med 2002;347:465-471.

12. Lieberman D, Lieberman D, Ben-Yaakov M, Lazarovich Z, Hoffman S, Ohana B, Friedman MG, Dvoskin B, Leinonen M, Boldur I. Infectious etiologies in acute exacerbation of COPD. Diagn Microbiol Infect Dis 2001;40:95-102.

13. Wedzicha JA. Role of viruses in exacerbations of chronic obstructive pulmonary disease. Proc Am Thorac Soc 2004;1:115-120.

14. Seemungal TA, Harper-Owen R, Bhowmik A, Jeffries DJ, Wedzicha JA. Detection of rhinovirus in induced sputum at exacerbation of chronic obstructive pulmonary disease. Eur Respir J 2000;16:677-683.

15. Wilkinson TM, Donaldson GC, Johnston SL, Openshaw PJ, Wedzicha JA. Respiratory syncytial virus, airway inflammation, and $\mathrm{FEV}_{1}$ decline in patients with chronic obstructive pulmonary disease. $\mathrm{Am}$ J Respir Crit Care Med 2006;173:871-876.

16. Meloni F, Paschetto E, Mangiarotti P, Crepaldi M, Morosini M, Bulgheroni A, Fietta A. Acute Chlamydia pneumoniae and Mycoplasma pneumoniae infections in community-acquired pneumonia and exacerbations of COPD or asthma: therapeutic considerations. J Chemother 2004;16:70-76.

17. Beaty CD, Grayston JT, Wang SP, Kuo CC, Reto CS, Martin TR. Chlamydia pneumoniae, strain TWAR, infection in patients with chronic obstructive pulmonary disease. Am Rev Respir Dis 1991;144: 1408-1410.

18. Anderson HR, Spix C, Medina S, Schouten JP, Castellsague J, Rossi G, Zmirou D, Touloumi G, Wojtyniak B, et al. Air pollution and daily admissions for chronic obstructive pulmonary disease in 6 European cities: results from the APHEA project. Eur Respir J 1997;10:1064-1071.

19. Dockery DW, Pope CA III, Xu X, Spengler JD, Ware JH, Fay ME, Ferris BG Jr, Speizer FE. An association between air pollution and mortality in six US cities. $N$ Engl J Med 1993;329:1753-1759.

20. MacNee W, Donaldson K. Exacerbations of COPD: environmental mechanisms. Chest 2000;117:390S-397S.

21. Pope CA III, Kanner RE. Acute effects of PM10 pollution on pulmonary function of smokers with mild to moderate chronic obstructive pulmonary disease. Am Rev Respir Dis 1993;147:1336-1340.

22. Pope CA III, Bates DV, Raizenne ME. Health effects of particulate air pollution: time for reassessment? Environ Health Perspect 1995;103: 472-480.

23. Sunyer J, Sáez M, Murillo C, Castellsague J, Martínez F, Antó JM. Air pollution and emergency room admissions for chronic obstructive pulmonary disease: a 5-year study. Am J Epidemiol 1993;137:701-705.

24. Rutten FH, Cramer MJ, Lammers JW, Grobbee DE, Hoews AW. Heart failure and chronic obstructive pulmonary disease: an ignored combination? Eur J Heart Fail 2006;8:706-711.

25. Harvey MG, Hancox RL. Elevation of cardiac troponins in exacerbation of chronic obstructive pulmonary disease. Emerg Med Australas 2004; $16: 212-215$.

26. Abroug F, Ouanes-Besbes L, Nciri N, Sellami N, Addad F, Hamda KB, Amor AB, Najjar MF, Knani J. Association of left-heart dysfunction with severe exacerbation of chronic obstructive pulmonary disease: diagnostic performance of cardiac markers. Am J Respir Crit Care Med 2006;174:990-996.

27. Tung RH, Camargo CA, Krauser D, Anwaruddin S, Baggish A, Chen A, Januzzi JL. Amino-terminal pro-brain natriuretic peptide for the diagnosis of acute heart failure in patients with previous obstructive airway disease. Ann Emerg Med 2006;48:75-76.

28. Connors AF Jr, Dawson NV, Thomas C, Harrell FE Jr, Desbiens N, Fulkerson WJ, Kussin P, Bellamy P, Goldman L, Knaus WA. Outcomes following acute exacerbation of severe chronic obstructive lung 
disease. The SUPPORT investigators (Study to Understand Prognoses and Preferences for Outcomes and Risks of Treatments). Am J Respir Crit Care Med 1996;154:959-967.

29. Weitzenblum E. The pulmonary circulation and the heart in chronic lung disease. Monaldi Arch Chest Dis 1994;49:231-234.

30. Lee-Chiong TL Jr, Matthay RA. Pulmonary hypertension and cor pulmonale in COPD. Semin Respir Crit Care Med 2003;24:263-272.

31. Rutschmann OT, Cornuz J, Poletti PA, Bridevaux PO, Hugli OW, Qanadli $\mathrm{SD}$, Perrier A. Should pulmonary embolism be suspected in exacerbation of chronic obstructive pulmonary disease? Thorax 2007;62:121-125.

32. Tillie-Leblond I, Marquette CH, Perez T, Scherpereel A, Zanetti C, Tonnel AB, Remy-Jardin M. Pulmonary embolism in patients with unexplained exacerbation of chronic obstructive pulmonary disease: prevalence and risk factors. Ann Intern Med 2006;145:390-396.

33. Stolz D, Christ-Crain M, Morgenthaler NG, Leuppi J, Miedinger D, Bingisser R, Muller C, Struck J, Muller B, Tamm M. Copeptin, C-reactive protein, and procalcitonin as prognostic biomarkers in acute exacerbation of COPD. Chest 2007;131:1058-1067.

34. Hurst JR, Donaldson GC, Perera WR, Wilkinson TM, Bilello JA, Hagan GW, Vessey RS, Wedzicha JA. Use of plasma biomarkers at exacerbation of chronic obstructive pulmonary disease. Am J Respir Crit Care Med 2006;174:867-874.

35. Dev D, Wallace E, Sankaran R, Cunniffe J, Govan JR, Wathen CG, Emmanuel FX. Value of C-reactive protein measurements in exacerbations of chronic obstructive pulmonary disease. Respir Med 1998; 92:664-667.

36. Hartmann IJC, Hagen PJ, Melissant CF, Postmus PE, Prins MH; ANTELOPE Study Group. Diagnosing acute pulmonary embolism: effect of chronic obstructive pulmonary disease on the performance of D-dimer testing, ventilation/perfusion scintigraphy, spiral computed tomographic angiography, and conventional angiography. Am J Respir Crit Care Med 2000;162:2232-2237.

37. Wagner PD, Dantzker DR, Dueck R, Clausen JL, West JB. Ventilationperfusion inequality in chronic obstructive pulmonary disease. J Clin Invest 1977;59:203-216.

38. Torres A, Reyes A, Roca J, Wagner PD, Rodriguez-Roisin R. Ventilationperfusion mismatching in chronic obstructive pulmonary disease during ventilator weaning. Am Rev Respir Dis 1989;140:1246-1250.

39. Keller CA, Ohar J, Ruppel G, Wittry MD, Goodgold HM. Right ventricular function in patients with severe COPD evaluated for lung transplantation. Lung Transplant Group. Chest 1995;107:1510-1516.

40. Hodgkin JE. Prognosis in chronic obstructive pulmonary disease. Clin Chest Med 1990;11:555-569.

41. Seneff MG, Wagner DP, Wagner RP, Zimmerman JE, Knaus WA. Hospital and 1-year survival of patients admitted to intensive care units with acute exacerbation of chronic obstructive pulmonary disease. JAMA 1995;274:1852-1857.

42. Anthonisen NR, Manfreda J, Warren CP, Hershfield ES, Harding GK, Nelson NA. Antibiotic therapy in exacerbations of chronic obstructive pulmonary disease. Ann Intern Med 1987;106:196-204.

43. Balter MS, La Forge J, Low DE, Mandell L, Grossman RF. Canadian guidelines for the management of acute exacerbations of chronic bronchitis: executive summary. Can Respir J 2003;10:248-258.

44. Ball P, Make B. Acute exacerbations of chronic bronchitis: an international comparison. Chest 1998;113:199S-204S.

45. Vestbo J. Clinical assessment, staging, and epidemiology of chronic obstructive pulmonary disease exacerbations. Proc Am Thorac Soc 2006; 3:252-256.

46. Turner MO, Patel A, Ginsberg S, FitzGerald JM. Bronchodilator delivery in acute airflow obstruction: meta-analysis. Arch Intern Med 1997;157:1736-1744.

47. Emerman CL, Cydulka RK. Effect of different albuterol dosing regimens in the treatment of acute exacerbation of chronic obstructive pulmonary disease. Ann Emerg Med 1997;29:474-478.

48. Dolovich MB, Ahrens RC, Hess DR, Anderson P, Dhand R, Rau JL, Smaldone GC, Guyatt G; American College of Chest Physicians; American College of Asthma, Allergy, and Immunology. Device selection and outcomes of aerosol therapy: evidence-based guidelines: American College of Chest Physicians/American College of Asthma, Allergy, and Immunology. Chest 2005;127:335-371.

49. MacIntyre NR. Corticosteroid therapy and COPD. Respir Care 2006; 51:289-296.

50. Saint S, Bent S, Vittinghoff E, Grady D. Antibiotics in chronic obstructive pulmonary disease exacerbations: a meta-analysis. JAMA 1995;273: 957-960.
51. Poole PJ, Black PN. Mucolytic agents for chronic bronchitis or COPD. Cochrane Database Syst Rev 2006;3:CD001287.

52. Hess DR. Conference summary: airway clearance techniques. Respir Care 2007;52:1392-1396.

53. Smith TC, Marini JJ. Impact of PEEP on lung mechanics and work of breathing in severe airflow obstruction. J Appl Physiol 1988;65:1488-1499.

54. Tremblay LN, Slutsky AS. Ventilator-induced lung injury: from the bench to the bedside. Intensive Care Med 2006;32:24-33.

55. Ranieri VM, Mascia L, Petruzzelli V. Inspiratory effort and measurement of dynamic intrinsic PEEP in COPD patients: effects of ventilator triggering systems. Intensive Care Med 1995;21:896-903.

56. Lightowler JV, Wedzicha JA, Elliott MW, Ram FS. Non-invasive positive pressure ventilation to treat respiratory failure resulting from exacerbations of chronic obstructive pulmonary disease: Cochrane systematic review and meta-analysis. BMJ 2003;326:185.

57. Hager DN, Krishman JA, Hayden DL, Brower RG; ARDS Clinical Trials Network. Tidal volume reductions in patients with acute lung injury when plateau pressures are not high. Am J Respir Crit Care Med 2005;172:1241-1245.

58. Gajic O, Frutos-Vivar F, Esteban A, Hubmayr RD, Anzueto A. Ventilator settings as a risk factor for acute respiratory distress syndrome in mechanically ventilated patients. Intensive Care Med 2005;31:922-926.

59. MacIntyre NR. The "best" tidal volume for managing ALI/ARDS. Respir Care Clin N Am 2004;10:309-315.

60. NIH ARDS Network. Ventilation with lower tidal volumes as compared with traditional tidal volumes for acute lung injury and the acute respiratory distress syndrome. $N$ Engl J Med 2000;342:1301-1308.

61. Hickling KG, Walsh J, Henderson S, Jackson R. Low mortality rate in adult respiratory distress syndrome using low-volume, pressure-limited ventilation with permissive hypercapnia: a prospective study. Crit Care Med 1994;22:1568-1578.

62. Kavanaugh BP. Therapeutic hypercapnia: careful science, better trials. Am J Respir Crit Care Med 2005;171:96-97.

63. Kregenow DA, Rubenfeld GA, Hudson LD, Swenson ER. Hypercapnic acidosis and mortality in acute lung injury. Crit Care Med 2006;34:1-7.

64. Marini JJ, Crooke PS. A general mathematical model for respiratory dynamics relevant to the clinical setting. Am Rev Respir Dis 1993;147: $14-24$.

65. MacIntyre NR, McConnell R, Cheng KC. Applied PEEP reduces the inspiratory load of intrinsic PEEP during pressure support. Chest 1997; 111:188-193.

66. Gay PC, Rodarte JR, Hubmayr RD. The effects of positive expiratory pressure on isovolume flow and dynamic hyperinflation in patients receiving mechanical ventilation. Am Rev Respir Dis 1989;139:621-626.

67. Kass JE, Castriotta RJ. Heliox therapy in acute severe asthma. Chest 1995;107:757-760.

68. American College of Chest Physicians; American Association for Respiratory Care; American College of Critical Care Medicine; MacIntyre NR. Evidence-based guidelines for weaning and discontinuing ventilatory support. Chest 2001; 120(Suppl)375S-395S.

69. Nava S, Ambrosino N, Clini E, Prato M, Orlando G, Vitacca M, Brigada $P$, Fracchia $C$, Rubini F. Noninvasive ventilation in the weaning of patients with respiratory failure due to COPD. Ann Intern Med 1998; 128:721-728.

70. Girault C, Daudenthun I, Chevron V, Tamion F, Leroy J, Bonmarchand G. Noninvasive ventilation as a systematic extubation and weaning technique in a cute on chronic respiratory failure. Am J Respir Crit Care Med 1999;160:86-92.

71. Dhand R. Inhalation therapy with metered-dose inhalers and dry powder inhalers in mechanically ventilated patients. Respir Care 2005;50:13311334.

72. MacIntyre NR. Aerosol delivery through an artificial airway. Respir Care 2002;47:1279-1288.

73. Groenewegen KH, Schols AM, Wouters EF. Mortality and mortalityrelated factors after hospitalization for acute exacerbation of COPD. Chest 2003;124:459-467.

74. Ai-Ping C, Lee KH, Lim TK. In-hospital and 5-year mortality of patients treated in the ICU for acute exacerbation of COPD: a retrospective study. Chest 2005;128:518-524.

75. Nevins ML, Epstein SK. Predictors of outcome for patients with COPD requiring invasive mechanical ventilation. Chest 2001;119:1840-1849.

76. Ucgun I, Metintas M, Moral H, Alatas F, Yildirim H, Erginel S. Predictors of hospital outcome and intubation in COPD patients admitted to the respiratory ICU for acute hypercapnic respiratory failure. Respir Med 2006;100:66-74. 